\title{
Investment Strategies in NBFCs
}

\author{
V. Uma Devi \\ M.Com.,MBA[Ph.D]
}

\begin{abstract}
N B F C$ 's have played a key role in financing the needs of the Indian industry especially the small and medium enterprises and the small entrepreneurs, both in the urban and the rural areas. While the underpenetration of banking network, rising affluence, large working age population and rising need for financial services point to the tremendous potential for the growth of NBFC's. A vigorous banking and financial sector is critical for facilitating higher economic growth. Financial intermediaries like Non-Banking Financial Companies (NBFCs) constitute a significant element of the financial system and have penetrated into those areas where banks did not dare by taking both the operational and regulatory risks.

NBFCS form an integral part of the Indian financial system. They have been very instrumental in contribution to the Government's agenda of financial inclusion by filling the important gap of supplying credit to retail customers in the relatively under-served and un-banked areas. They play an active complementary role to the banking system by broadening access to financial services, enhancing competition and diversification of financial sector. NBFCs are known for their higher risk taking capacity than the banks. The intention of this study is to analyze the investment strategies of non-bank finance companies (NBFCS) which are providing the financial services.
\end{abstract}

Key words: NBFCs, Financial System, Investment strategies, Financial Services etc.

\section{Introduction}

NBFCs form a significant segment of the shadow banking system; play an important role in broadening access to financial services and enhancing competition and diversification of the financial sector. Over the years, NBFCs have become a crucial part of the Indian financial system, accounting for around $12 \%$ of the assets of the total financial system. NBFCs have emerged an important intermediary for financing and have provided strong competition to banks and financial institutions.

The Reserve Bank of India regulates and supervises Non-Banking Financial Companies which are into the business of loans and advances, acquisition of shares/stocks/bonds/ debentures / securities issued by Government or local authority or other marketable securities of a like nature, leasing, hire-purchase, insurance business, chit business but does not include any institution whose principal business is that of agriculture activity, industrial activity, purchase or sale of any goods (other than securities) or providing any services and sale/purchase/construction of immovable property.

Residuary Non-Banking Company is a class of NBFCs whose 'principal business' is to receive deposits, under any scheme or arrangement or in any other manner. These companies are not into Investment, Asset Financing or Lending. Functioning of these companies is different from that of NBFCs in terms of method of mobilization of deposits and requirement of deployment of depositors' funds. These companies, however, have now been directed by the Reserve Bank not to accept any deposits and to wind up their businesses as RNBCs.

The Reserve Bank of India expert committees identified the need of non banking financial companies in the following areas:

$>$ Development of sectors like transport and infrastructure

$>$ Substantial employment generation

$>$ Help and increase wealth creation

$>$ Broad base economic development

$>$ Irreplaceable supplement to bank credit in rural segments

$>$ Major thrust on semi-urban, rural Areas and first time buyers/users

$>$ To finance economically weaker sections.

$>$ Huge contribution to the state exchequer.

\section{Review of Literature}

Chris Geczy (2013) said "Investment style is incredibly important because of the way that investing works, both risk and return are connected to style. According to current practice portfolio theory, you can optimize a blend of styles for diversification, balancing reward and risk." 
M. R. Shollapur (1991) conducted a study on the financial institutions whose principal business is the acquisition of securities. For this purpose, they collect funds from generally the household savers, through specific financial instruments (unit/share/debenture) and invest these pooled funds in suitable securities. In general, the basic objective of such investment companies is to get enhanced benefits of huge and pooled resources through low risk and expertise. The major investment companies in India include investment trusts, mutual funds, and common trust funds of commercial banks, management investment companies, and unit trusts.

Hayman (2010) said "Fundamental analysis involves evaluating all the factors that affect an investment's performance. For a stock, it would mean looking at all of the company's financial information, and it may also entail meeting with company executives, employees, suppliers, customers and competitors. "You want to analyze management, really understand what's driving the company and where growth is coming from,"

SIDBI Fund manager (2013) stated the points on size of investment that the assistance shall normally not exceed ' 3 crore per MFI. In the event of transformation of the Non-corporate MFI into a NBFC, the assistance could be converted into equity shares, And the assistance to NBFC-MFI or Section 25 companies, including equity assistance, shall normally not exceed ' 3 crore, subject to regulatory requirements, if any.

\section{Need of the study}

The present study is empirical and descriptive in nature. The study is confined to examine the state of Non Banking Financial Institutions in India by new financial regulations given by RBI Deposit taking \& NonDeposit taking and its investment strategies.

\section{Objectives}

The present study has been conducted to analyze the investment strategies in NBFCs. The specific objectives of the study are

1. To study the funding sources of NBFCs

2. To study the investment strategies of NBFCs

3. To study the investment philosophy rooted in NBFCs

\section{Research methodology}

The study is descriptive and investigative in nature . The data is collected through internet, to the large extent the paper is based on the secondary data. The period of the study is from 2008-09 to 2012-13; it has been tabulated and analyzed theoretically.

\section{Funding source of NBFC sector}

Funding source of NBFCs comprises debentures, borrowings from banks and FIs, public deposits, commercial papers, and inter-corporate loans. In FY12, borrowings from banks and FIs, followed by debentures, constituted an important source of funds for NBFCs-D. Borrowings from banks and FIs accounted for 50\% and debentures accounted for $29 \%$ of the total borrowings of NBFCs-D in FY12. Debentures form an important source of funds for NBFCs-ND-SI. In FY12, debentures accounted for $46 \%$ and borrowings from banks and FIs counted for $32 \%$ of the total borrowings of NBFCs-ND-SI.

As at the end of FY12 balance sheet size of NBFC-D stood at Rs 1,169 billion registering an increase of around 11\% y-o-y. As of March 2012, more than two-thirds of NBFCs-D sector's total assets were held by AFCs. Component wise, the advances accounted for a predominant share of the total assets, followed by investments. Borrowings, a major source of funding, grew $15.9 \%$ and public deposits which are subjected to credit rating, continued to show an increasing trend, with $43.8 \%$ growth. However, total Investments registered a $24.8 \%$ decline due to $0.7 \%$ and $67.6 \%$ decline in SLR and Non-SLR investments. The ratio of public deposit to own funds improved marginally and stood at 29.99\% as at end-March 2012, as against 23.89\% in 2011.

\begin{tabular}{|c|c|c|c|c|c|c|}
\hline \multicolumn{7}{|c|}{$\begin{array}{l}\text { Table.1.Aggregate D } \\
\text { (Amount in Rs. Billion) }\end{array}$} \\
\hline \multirow{2}{*}{\begin{tabular}{|c} 
Year \\
(End-March)
\end{tabular}} & \multicolumn{2}{|l|}{ NBFC } & \multicolumn{2}{|l|}{ RNBC } & \multirow{2}{*}{$\begin{array}{l}\text { Total } \\
\text { Deposits }\end{array}$} & \multirow{2}{*}{ Public } \\
\hline & $\begin{array}{l}\text { No of } \text { Reporting } \\
\text { Companies }\end{array}$ & $\begin{array}{l}\text { Public } \\
\text { deposits }\end{array}$ & $\begin{array}{l}\text { No of } \quad \text { Reporting } \\
\text { companies }\end{array}$ & $\begin{array}{l}\text { Public } \\
\text { deposits }\end{array}$ & & \\
\hline 2008-09 & 336 & 19.71 & 2 & 195.95 & 215.66 & \\
\hline 2009-10 & 308 & 28.31 & 2 & 145.21 & 173.52 & \\
\hline $2010-11$ & 297 & 40.98 & 2 & 79.02 & 120.00 & \\
\hline 2011-12 & 271 & 57.35 & 2 & 42.65 & 100.00 & \\
\hline $2012-13$ & 254 & 70.85 & 2 & 35.01 & 105.86 & \\
\hline
\end{tabular}




\section{Investment Strategies \\ Debt Strategy}

The fixed income portfolio will be invested in debt securities maturing in line with the maturity of scheme. The fixed income strategy would to buy and hold. The debt portfolio is largely run as an accrual income product and will be passively managed. The Fixed income portion is intended to be invested across sectors and in AA and AAA \& Equivalent rated debt securities. The investment philosophy for fixed income investments follows from the objective to deliver optimal risk-adjusted returns across the products.

A combination of top down and bottom up approaches are used to construct portfolios. Global and local macro-economic variables such as growth indicators, inflation outlook, currency changes, liquidity, etc. are analyzed to determine the long-term and short-term trends. Short-term, cyclical economic considerations are used to fine-tune the duration of the portfolios.

The investment universe includes government securities, corporate bonds, mortgages backed securities, and asset backed securities and money market instruments. We make asset allocation changes within this universe depending upon changes in relative valuations / spreads and the forward outlook for them. We maintain high credit quality portfolios across the board. Normally, portfolios have more than $85 \%$ in AA or higher rated assets. Credit risks are assumed after internal due diligence.

The investment strategy of individual funds follows from the investment philosophy enunciated above and is fine tuned to suit the respective investment objectives of the funds.

\section{Equity Strategy}

The equity exposure would be in equity \& equity-related instruments, primarily through long call options on Nifty, with expiry near to the maturity of the scheme. The equity derivative strategy would endeavor to provide exposure to equities by buying call options. The participation rate would depend on the prevailing prices of the option contract. The total Equity exposure of the fund will be in the range of 5\%-20\%. The Fund intends to buy call options with December 2014 expiry, and may invest some portion into large cap stocks for the remaining tenor of the fund.

\section{Investment Philosophy}

The overall investment philosophy stems from our objective of delivering superior risk adjusted returns to investors over an extended time frame. The investment philosophy is rooted in a set of well established but flexible principles that relies extensively on fundamental research. It is driven by the belief that over time stock prices reflect a business' underlying intrinsic values and its long-term prospects. As a result, the research process aims to arrive at a comprehensive understanding of a company's business including the nature of its interactions with customers, suppliers, competitors and regulators. The ideas is to identify superior businesses with growing and predictable cash flows run by competent management. When valuing businesses, we take the perspective of a co-owner of the business and thus lean heavily on the concept of cash flows and economic earning power. In addition, we rely on various earnings multiples besides analyzing private market value and appropriate regional and global comparisons.

The basic principles that serve as the foundation for the above investment approach are:

\section{Managing risk}

Our aim is to purchase stocks at a price that represents a material discount to their long-term intrinsic value or at a price that is attractive from a relative value standpoint. Doing so explicitly recognizes the importance of capital preservation and provides a supportable underlying value that provides some insulation if actual outcomes are milder than initially forecast. This is consistent with a long-term, business-like approach to investing and allows for the challenges that companies will possibly face in a competitive and fast-changing market. Besides looking at risk of an individual investment decision, we also thoroughly analyze and aim to manage overall portfolio risk.

\section{Maintain a balanced outlook on the market}

Downside risks to financial stability persist. In a number of markets, including several emerging markets, asset valuations could come under pressure if interest rates rose more than expected and adversely affected investor sentiment.

We do not believe in taking a call on the near term direction of the market indices. We avoid market timing and as a result, except for extenuating circumstances, our funds do not make substantial cash allocations. The same market mechanism that creates the opportunity for successful long-term returns also presents volatility and accompanying anxieties in the short term. As long-term investors, we feel it is appropriate to maintain the 
patience and discipline that is demanded at such times and to the extent possible take advantage of such uncertainty.

Through the active management process, we aim to achieve higher risk-adjusted returns over time across all our products. Following the above investment philosophy in a disciplined manner has worked well for us as is attested by the steady out performance of our range of equity products over three, five and ten year periods. Success skill in managing the investments lies in achieving the right balance between risks and returns. Where risk is high, returns can also be expected to be high and vice versa.

\section{Focus on the long term}

There is substantive empirical evidence to suggest that equities as an asset class have provided superior risk adjusted returns over the long term. However, over short periods of time equity returns can be quite volatile influenced by fluctuating investor emotions and temporary fads. Additionally, different investment styles, sectors and approaches come in and out of favor distorting short-term performance. Longer-term returns are driven by economic fundamentals. As a result prices and fundamentals do decouple over shorter periods but tend to converge over time.

The following four NBFCs are playing vital role in India

$>$ Housing Development Finance Corporation Limited

$>$ Power Finance Corporation Limited

$>$ Rural Electrification Corporation Limited

$>$ Infrastructure Development Finance Company Limited

\section{Housing Development Finance Corporation Limited:}

Housing Development Finance Corporation Limited is shortly called as HDFC, which was incorporated in the year 1997 with the objective of offering long-term finance to households to meet their housing requirements. HDFC is basically engaged in the promotion of housing ownership by offering long-term finance to households. Some of the products offered by them are land purchase loans, home equity loans, shortterm bridge loans, home extension loans, home improvement loans and home loans.

Power Finance Corporation Limited: Power Finance Corporation Limited came into existence in the year 1986 with the objective of promoting the power sector in the nation. The company is engaged in offering finance for implementation of power projects and for development of new power plants. The company offers both non-financial and financial support to power equipment manufacturing firms, municipal bodies, cooperative societies, private sector power companies, joint sector power companies, central power companies and state electricity departments.

PFC has been providing financial assistance to power projects across India including generation, transmission, distribution and RM\&U projects. Recently, it has forayed into financing of other infrastructure projects which have backward linkages to the power sector like coal mine development, fuel transportation, oil $\&$ gas pipelines etc. The borrower profile includes State Electricity Boards, State sector power utilities, Central sector power utilities and Private sector companies.. The company also has the mechanism of rating different state Power Utilities on its performance.

Rural Electrification Corporation Limited: Rural Electrification Corporation Limited shortly called as REC came into existence in the year 1969 for the purpose of promotion of rural electrification projects in the country. The company became an NBFC in the year 1998 and it plays a crucial role in expansion, modernization and creation of power infrastructure in all segments. REC's business model spans across the value chain of power infrastructure financing including equipment finance, technical/ financial appraisal of project, project finance as well as short term or bridge loans for generation, intensive electrification, transmission, distribution, repair and maintenance, and support functions like project monitoring, consultancy and advisory.

It is also offering financial support to emerging areas like non-conventional energy and decentralized distributed generation.

Infrastructure Development Finance Company Limited: Infrastructure Development Finance Company Limited shortly called as IDFC came into existence in the year 1997 in the Indian state of Tamil Nadu. In the year 2005, it became a public entity and it is engaged in offering project finance, asset management, investment banking, principal investment \& treasury and project finance services. The business activities of this NBFC can be divided into two types namely fund-based and non-fund based businesses. 
VI. Findings and Recommendations:

The following table shows the investments patterns of four companies.

Table.2. Investments during years 2011, 12 \& 13 (Rs. in Crores)

\begin{tabular}{|l|c|c|c|}
\hline \multicolumn{1}{|c|}{ NBFCs } & FY 2011 & FY 2012 & FY 2013 \\
\hline Power Finance Corporation LTD & 26.63 & 26.83 & 56.38 \\
\hline $\begin{array}{l}\text { Housing Development Finance } \\
\text { Corporation }\end{array}$ & $11,832.42$ & $12,207.00$ & $13,613.46$ \\
\hline Rural Electrification Corporation LTD & 757.59 & 758.00 & 661.00 \\
\hline $\begin{array}{l}\text { Infrastructure Development Financial } \\
\text { Company LTD }\end{array}$ & $8,107.42$ & $8,485.71$ & $11,272.40$ \\
\hline
\end{tabular}

\section{Investments during years 2011, 12 \& 13}

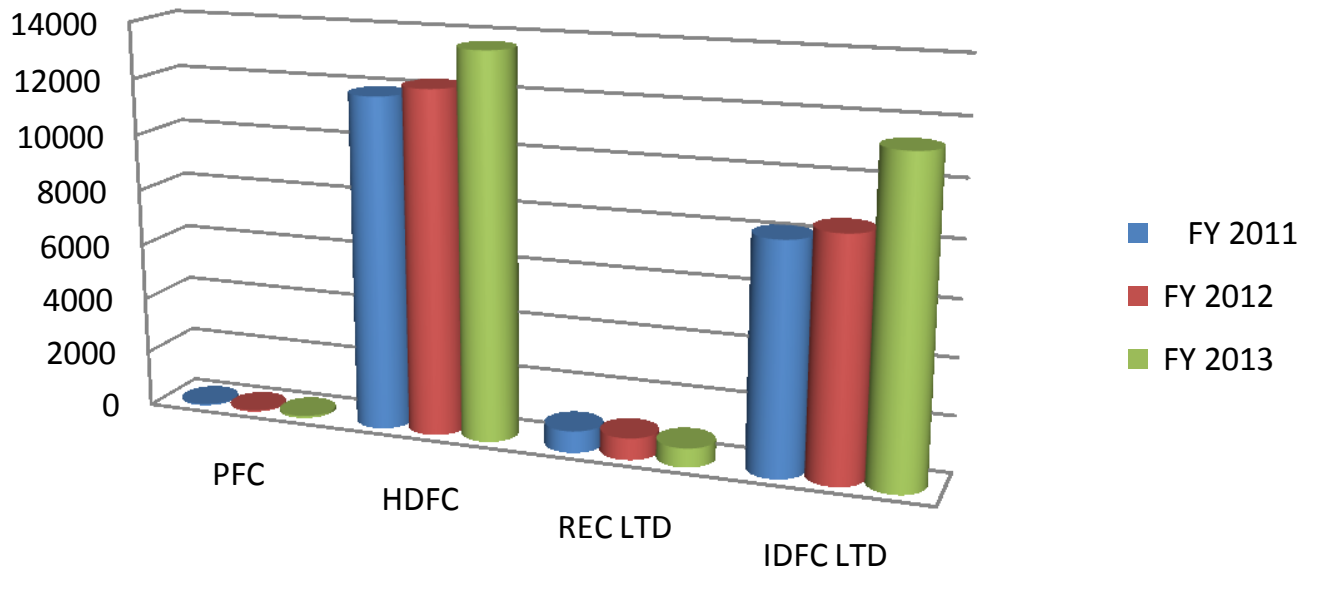

Non-Banking Finance Companies (NBFCs) in India were severely impacted due to economic slowdown coupled with fall in demand for financing as several businesses deferred their expansion plan. Stock prices of NBFCs' crashed on the back of rising non-performing assets and several companies closed their operations. International NBFCs' still continue to close down or sell their back end operations in India.

The positive news however is that, this crisis has forced NBFCs to improve their operations and strategies. Industry experts opine that they are much more mature today than they were during the last decade. Timely intervention of RBI helped reduce the negative effect of credit crunch on banks and NBFCs. In fact, aggressive strategies helped LIC Housing Finance to grab new customers (including customers of other banks) and increase its market share in national mortgage market. Surprisingly it was able to maintain its profitability in 2009 (around 37\%). HDFC, the largest NBFC in India, however experienced a slowdown in customer growth due to stiff competition, especially from LIC Housing Finance and tight monetary conditions. Other NBFCs that were stable during this period of credit crunch are Infrastructure Development Finance Company (IDFC) Power Finance Corporation (PFC) and Rural Electrification Corporation (REC). Growth prospects are strong for these companies given the acute shortage of power in the country and expected increase in demand for infrastructure projects. The segment which was hit hardest was Vehicle Financing. Companies financing new vehicle purchases experienced a drastic reduction in new customer numbers. Fortunately, since vehicle finance is assetbased business, their asset quality did not suffer as against other consumer financing businesses.

\section{Results and Discussions}

Non-banking finance companies, or NBFCs, did exceptionally well in 2012. While stocks of nearly 20 NBFCs more than doubled during the year, more than 30 NBFC stocks listed on the Bombay Stock Exchange, or BSE, beat the Sensex, which rose 25 per cent during the year. The clarification could allay the concerns of non-banking financial firms (NBFC), which rely heavily on capital markets to fund their businesses but have attracted less regulatory oversight than banks.

The Reserve Bank recently relaxed norms for non-banking finance companies (NBFCs) in insurance joint ventures by allowing them to hold more than 50 percent in such companies. The Reserve Bank said 
balance-sheets of deposit-taking non-banking financial companies grew marginally by 2.2 percent to Rs 1 , 24,900 crore in the financial year ended March 2013.

\section{Conclusion}

NBFCs have come a long way from an era of concentrated regional operations, low credibility and poor risk management practices to highly sophisticated operations, pan-India presence and most importantly an alternate choice of financial intermediation. NBFCs' growth had been constrained due to lack of adequate capital. Going forward, we believe capital infusion and leverage thereupon would catapult NBFCs' growth in size and scale.

A number of NBFCs have been issuing non-convertible debentures (NCDs) in order to increase their balance sheet liquidity. Also to address this purpose, especially in the infrastructure financing space, a new category of NBFCs was formed called Infrastructure financing companies (IFCs). A common feature in all the advanced economies is their financial systems are well developed to deliver a wide range of financial services and sophisticated products at competitive price that are demanded by the sophisticated clientele. This was possible because of institutions such as NBFIs that were found to be more aggressive and innovative. More importantly, it resulted in improving the efficiency by inciting competition between NBFIs and banking system and ultimately stated to have contributed to macroeconomic stability and sustained economic growth.

\section{References:}

[1]. Financial Institutions and markets., L.M.Bhole., Tata McGraw Hill Publishers

[2]. www.rbi.org.in

[3]. www.recindia.nic.in

[4]. www.shodhganga.inflibnet.ac.in

[5]. www.roberthurdman.com

[6]. www.profit.ndtv.com

[7]. www.rediff.com

[8]. www.moneycontrol.com

[9]. www.dnb.co.in

[10]. www.bankrate.com/finance/investing/common-investment-strategies 